\title{
Microbiological quality of beef, mutton, and water from different abattoirs in the Eastern Cape Province, South Africa
}

\author{
Philisani Ncoko ${ }^{1}$, Ishmael Festus Jaja1,2(i) and James Wabwire Oguttu² (iD \\ 1. Department of Livestock and Pasture, University of Fort Hare, Private Bag X1314, Alice, 5700, Eastern Cape Province, \\ South Africa; 2. Department of Agriculture and Animal Health, University of South Africa, Florida Campus, Johannesburg, \\ 1709, South Africa. \\ Corresponding author: Ishmael Festus Jaja, e-mail: ijaja@ufh.ac.za \\ Co-authors: PN: khangelanipncoko@gmail.com, JWO: joguttu@unisa.ac.za \\ Received: 20-10-2019, Accepted: 20-05-2020, Published online: 18-07-2020
}

doi: www.doi.org/10.14202/vetworld.2020.1363-1371 How to cite this article: Ncoko P, Jaja IF, Oguttu JW (2020) Microbiological quality of beef, mutton, and water from different abattoirs in the Eastern Cape Province, South Africa, Veterinary World, 13(7): 1363-1371.

\begin{abstract}
Background and Aim: Abattoir processes from skinning, evisceration, to chilling usually lead to meat contamination by foodborne pathogens. Hence, continual microbial surveillance of slaughter carcasses by veterinary public health officials is key to preventing contamination and outbreak of meat-related foodborne diseases. This study was conducted to determine the Enterobacteriaceae count and aerobic plate count (APC) and to detect Escherichia coli and Salmonella spp. in meat and water from selected slaughter facilities.
\end{abstract}

Materials and Methods: Retrospective data $(n=100)$ collected in 2017 by the Provincial Veterinary Department of the Eastern Cape Province from abattoirs and prospective survey data of meat $(n=50)$ collected in 2018 from abattoirs in the Eastern Cape Province were utilized in this study. APC and Enterobacteriaceae were enumerated from the samples. In addition, Salmonella and E. coli were isolated from samples using selective media.

Results: The APC in both retrospective and prospective studies for all samples ranged between 2 and 4.50 log CFU/ $\mathrm{cm}^{2}$; similar counts of 2-4.00 $\log \mathrm{CFU} / \mathrm{cm}^{2}$ were recorded for Enterobacteriaceae. No significant difference (p>0.05) for APC and Enterobacteriaceae count across all meat types was noted. Salmonella and E. coli were detected in $50 \%$ of beef. E. coli was not detected from mutton, but Salmonella was found in $66.7 \%$. Moreover, $91.7 \%$ of the water samples had E. coli, but none had Salmonella.

Conclusion: The levels of Enterobacteriaceae and APC observed in meat satisfy regulatory conditions outlined by the Department of Agriculture, Forestry and Fisheries, South Africa and show that meat produced from these abattoirs is of acceptable microbial quality. However, the quality of water used in the abattoirs does not meet the requirements set by the government, and contributes to contamination of meat produced in the abattoirs under study. Therefore, we recommend that sources of water be continuously investigated to eliminate or reduce the risk of contamination of meat processed in the abattoirs.

Keywords: contamination, foodborne pathogens, hygiene, meat spoilage, water quality.

\section{Introduction}

Meat is an outstanding source of protein in human diets, but because of its biochemical composition, it is highly susceptible to microbial contamination. The contamination of meat usually leads to severe spoilage and foodborne infections [1]. Meatborne pathogens are easily transferred to meat from the animal gastrointestinal tract, the environment, and the meat handler's hands, especially in poor sanitary conditions. Recent studies have indicated that consumers are now searching for healthier and nutritious meat [2].

A large proportion of the South African population is reliant on mutton, chicken, beef, and pork as

Copyright: Ncoko, et al. Open Access. This article is distributed under the terms of the Creative Commons Attribution 4.0 International License (http://creativecommons.org/licenses/by/4.0/), which permits unrestricted use, distribution, and reproduction in any medium, provided you give appropriate credit to the original author(s) and the source, provide a link to the Creative Commons license, and indicate if changes were made. The Creative Commons Public Domain Dedication waiver (http://creativecommons.org/ publicdomain/zero/1.0/) applies to the data made available in this article, unless otherwise stated. their source of protein, predisposing them to infection if contaminated $[3,4]$. Consuming contaminated meat is the principal transmission route for foodborne disease. Pathogens, including Campylobacter, Staphylococcus, Escherichia coli, Salmonella, and Enterococci, are listed as the top five food pathogens worldwide [5]. These pathogens have been identified as the causative agents of millions of infection and mortality globally [6]. In developing countries, around $33 \%$ of the population are affected by foodborne illnesses yearly [7]. Moreover, an estimated 230,000 or $40 \%$ of the infections due to non-typhoidal Salmonella enterica occur in children, resulting in mortality [8]. In the WHO subregion, AFR D and E circa 2012, around 10,200 cases of Shiga toxin-producing $E$. coli food-related illnesses were reported [9].

Hundreds of livestock for both domestic and international meat markets are processed in abattoirs in South Africa. Process stages, including stunning, skinning, scalding, evisceration, and chilling are sensitive critical control points (CCP) for microbial contamination prevention. 
Microbial testing of meat after slaughter ensures that hygiene breaches are corrected in record time. However, this is seldom done in some provincial abattoir, necessitating the need for this study [10].

Even though a few studies have reported the health risks associated with consuming meat and meat products in some provinces in South Africa, there are few studies on the microbiological quality of meat and water in abattoirs in the ECP. Hence, the objective of the current study was to evaluate the microbiological quality of meat and water in different abattoirs in the province.

\section{Materials and Methods}

\section{Ethical approval}

The University of Fort Hare Ethics Committee (MUC551SNCO01) approved all the protocols that were used in the experiments carried out in this study.

\section{Description of the study site}

The Eastern Cape Province is the second-largest province in South Africa (SA), with an estimated population of $6,522,700$ based on the mid-year population estimates of 2018 [11]. The ECP is one of the provinces with a high number of livestock. The number of cattle, sheep, and goats in the province is estimated to be 3.139 million, 6.615 million, and 2.085 million, respectively [12]. The province's vast landmass caters for various farming systems ranging from communal farming to commercial farming. These farming systems practice different production systems, including extensive, semi-intensive, and intensive production systems. The ECP has more than 70 abattoirs that cater for both red meat and poultry slaughter. These abattoirs are distributed across six district municipalities of the Eastern Cape, and include: Hani, O.R Tambo, Joe Gqabi, Alfred Nzo, Amathole, and Sarah Baartman district municipalities.
Collection of retrospective data $(R D)$ and prospective survey (PS)

A retrospective data $(\mathrm{RD})$ of the microbial survey of meat from March 2017 to December 2017 collected by the Provincial Veterinary Department, Veterinary Public Health Unit, were included in this study. The $\mathrm{RD}$ consisted of a microbial count for both beef and mutton. A prospective survey (PS) was also carried out in different abattoirs from the six districts such as Alfred Nzo, Amathole, Chris Hani, Joe Gqabi, Sarah Baartman, and O.R Tambo District Municipalities (Table-1). In the PS, samples of beef, mutton, and water were collected from January 2018 to November 2018.

\section{Sampling of carcasses and collection of samples}

The sampling was performed following the completion of carcass dressing before the commencement of chilling. Carcasses were sampled once a month. The samples were taken halfway through the slaughter day and on the sampling day to acquire samples that are representative of the factory's daily throughput. The swabs from each carcass were sufficiently labeled and placed in a sterile container containing $100 \mathrm{~mL}$ of sterile diluent and transported to the laboratory at $4^{\circ} \mathrm{C}$ between 8 and $24 \mathrm{~h}$.

Swabs were moistened before the collection of samples with the use of sterile maximum recovery diluent $0.1 \%$ peptone and $0.85 \% \mathrm{NaCl}$ for a minimum of $5 \mathrm{~s}$. The swabs were taken from the carcass by swabbing diagonally, horizontally, and vertically for not $<20 \mathrm{~s}$ with the use of a sterile $100 \mathrm{~cm}^{2}$ template and as much pressure as possible. The surface area for swabbing was approximately $100 \mathrm{~cm}^{2}$. Swabbing of different carcasses was done in the following manner: Bovine (neck, brisket, flank, and rump) first and then ovine (flank, lateral thorax, brisket, and breast).

Table-1: Abattoir location, classification of facility and species slaughtered at facility.

\begin{tabular}{|c|c|c|c|c|}
\hline Number & Abattoir Location & Coordinates & Classification of facility & Species slaughtered \\
\hline 1 & Stutterheim & $32.5885^{\circ} \mathrm{S}, 27.4321^{\circ} \mathrm{E}$ & High throughput & Poultry \\
\hline 2 & East London & $33.0292^{\circ} \mathrm{S}, 27.8546^{\circ} \mathrm{E}$ & Rural throughput & Poultry \\
\hline 3 & Stutterheim & $32.5885^{\circ} \mathrm{S}, 27.4321^{\circ} \mathrm{E}$ & Rural Throughput & Poultry \\
\hline 4 & Indwe & $31.4803^{\circ} \mathrm{S}, 27.3440^{\circ} \mathrm{E}$ & Low Throughput & Cattle and Sheep \\
\hline 5 & East London & $33.0292^{\circ} \mathrm{S}, 27.8546^{\circ} \mathrm{E}$ & High Throughput & Sheep, Cattle and Pigs \\
\hline 6 & Maclear & $31.0638^{\circ} \mathrm{S}, 28.3345^{\circ} \mathrm{E}$ & Rural Throughput & Sheep, Cattle and Pigs \\
\hline 7 & Tsolo & $31^{\circ} 19^{\prime} 0^{\prime \prime} \mathrm{S}, 28^{\circ} 45^{\prime} 0^{\prime \prime} \mathrm{E}$ & Rural Throughput & Cattle and Sheep \\
\hline 8 & East London & $33.0292^{\circ} \mathrm{S}, 27.8546^{\circ} \mathrm{E}$ & High Throughput & Cattle, Sheep, Game and Pigs \\
\hline 9 & Elliot & $31.3130^{\circ} \mathrm{S}, 27.8370^{\circ} \mathrm{E}$ & High throughput & Cattle and Sheep \\
\hline 10 & Matatiele & $30.3621^{\circ} \mathrm{S}, 28.8014^{\circ} \mathrm{E}$ & Low Throughput & Cattle, Sheep and Pigs \\
\hline 11 & Queenstown & $31.9127^{\circ} \mathrm{S}, 26.9597^{\circ} \mathrm{E}$ & High Throughput & Cattle and Sheep \\
\hline 12 & Adelaide & $34.9285^{\circ} \mathrm{S}, 138.6007^{\circ} \mathrm{E}$ & High Throughput & Game \\
\hline 13 & Komga & $32.5906^{\circ} \mathrm{S}, 27.8839^{\circ} \mathrm{E}$ & Low Throughput & Sheep and Cattle \\
\hline 14 & Barkly East & $30.9691^{\circ} \mathrm{S}, 27.5907^{\circ} \mathrm{E}$ & Rural Throughput & Cattle, Sheep and Pigs \\
\hline 15 & Komga & $32.5906^{\circ} \mathrm{S}, 27.8839^{\circ} \mathrm{E}$ & Low throughput & Cattle, Sheep and Pigs \\
\hline 16 & Molteno & $31^{\circ} 24^{\prime} 0^{\prime \prime} \mathrm{S}, 26^{\circ} 33^{\prime} 0^{\prime \prime} \mathrm{E}$ & Low Throughput & Sheep and Pigs \\
\hline 17 & Adelaide & $34.9285^{\circ} \mathrm{S}, 138.6007^{\circ} \mathrm{E}$ & Low Throughput & Cattle, Sheep and Pigs \\
\hline 18 & Aliwal North & $30^{\circ} 42^{\prime} 0^{\prime \prime} \mathrm{S}, 26^{\circ} 42^{\prime} 0^{\prime \prime} \mathrm{E}$ & Low Throughput & Cattle, Sheep and Pigs \\
\hline
\end{tabular}

E- East, S- South, High throughput ( $<50$ units to $>100$ units), Low throughput (Cattle 20 units, sheep and goats 40 units and Pigs 30 units), Rural throughput (Maximum of two units/ per day) 1 unit $=1$ cattle or 6 sheep or 5 pigs or 4 ostriches 


\section{Microbial count}

\section{Aerobic plate count (APC) and Enterobacteriaceae}

According to the International Organization for Standardization recommendation (ISO 21528-2, 2009), $25 \mathrm{~g}$ of each sample was utilized for culturing. The sample was poured in a stomacher bag. The weighed sample was then added to $9 \mathrm{~mL}$ of buffer peptone water (Lasec, South Africa), giving a 1:10 dilution. The samples in the buffer peptone water were poured into a stomacher bag (Bag mixer ${ }^{\mathbb{}}$ DOA 20550). The stomacher bag with the sample was placed in a bag mixer machine and mashed for $3 \mathrm{~min}$. Afterward, $0.1 \mathrm{~mL}$ of the test sample was transferred into two Petri dishes with the use of a sterile pipette.

APC was acquired by including $0.1 \mathrm{~mL}$ of the suspension and a series of ten-fold dilutions $\left(10^{-1}, 10^{-2}\right.$, and $\left.10^{-3}\right)$ in duplicate onto plate count agar plates ([PCA] Lasec, South Africa). The prepared plates were inverted and then placed in an incubator at $30 \pm 1^{\circ} \mathrm{C}$ for $72 \mathrm{~h} \pm 3 \mathrm{~h}$. Following incubation, bacteria colonies on plates were counted with the use of a colony counter-digital machine (Lasec, South Africa). For Enterobacteriaceae enumeration, $1 \mathrm{ml}$ of the sample was placed on the violet-red bile glucose agar, and a series of ten-fold dilutions $\left(10^{-1}, 10^{-2}\right.$, and $\left.10^{-3}\right)$ was duplicated. The plates were incubated for $24 \mathrm{~h}$ at $37^{\circ} \mathrm{C}$. Colony counting was performed, and colonies that appeared pink to red or purple were chosen and subjected to biochemical confirmation tests (oxidase test and glucose fermentation test) following international standards (ISO 21528-2, 2004).

E. coli

E. coli was identified in accordance with the International Organization for Standardization guidelines (ISO 16649-2, 2001). Twenty-five grams of the samples were emptied in a stomacher bag (Bag Mixer ${ }^{\circledR}$ DOA 20550) and added to $225 \mathrm{ml}$ of peptone buffered water. The stomacher bag with the sample was then placed in a bag mixer machine and mashed for $3 \mathrm{~min}$. Afterward, $0.1 \mathrm{ml}$ of the test sample was transferred into the tubes with the use of a sterile pipette. Then, the mixture was incubated at $37^{\circ} \mathrm{C}$ for $24 \mathrm{~h}$ [13]. The identification of $E$. coli was performed in accordance with the International Organization for Standardization guidelines, with the use of the most probable number technique (ISO 16649-2 2003). The tubes exhibiting gas production were recorded as positive, and a loop-full from each positive gas tube was transferred to a separate tube with MacConkey Broth (Oxoid, UK). E. coli confirmation was achieved by observing the gas production and acidification during growth in MacConkey Broth (Oxoid, UK). The positive results were streaked onto tryptone bile glucuronic agar (TBX agar, Oxoid, UK), and the plates were incubated at $37^{\circ} \mathrm{C}$ for $24 \mathrm{~h}$. The pink colonies were counted using a colony counter-digital machine (Lasec, South Africa) and further subjected to indole and catalase tests.

\section{Salmonella spp.}

Twenty five grams ( $25 \mathrm{~g})$ of each sample was weighed and emptied into a stomacher bag (Bag Mixer ${ }^{\mathbb{R}}$ DOA 20550), to which $225 \mathrm{ml}$ of peptone buffered water was added. Each sample was processed in accordance with the International Organization for Standardization methods (ISO 6579, 2002). The stomacher bag was placed in a bag mixer machine to homogenize the sample. The contents of the stomacher bag were emptied into a $250 \mathrm{ml}$ flat-bottom flask, which was already marked for identification. For the pre-enrichment stage, the flask was placed in an incubator (Labcon model: South Africa) at $37^{\circ} \mathrm{C}$ for $24 \mathrm{~h}$. Following incubation, $0.1 \mathrm{ml}$ of the pre-enriched broth was emptied onto Modified Semi-Solid Rappaport-Vassiliadis (MSRV) Agar (MSRV; Merck, Darmstadt, Germany) and incubated at $44^{\circ} \mathrm{C}$ for 24 h. After $24 \mathrm{~h}$, a loopful was taken from MSRV and streaked onto Xylose Lysine Deoxycholate (XLD) Agar (XLD; Merck, Darmstadt, Germany) plates and inoculated at $37^{\circ} \mathrm{C}$ for $24 \mathrm{~h}$. The colony count was performed following the completion of incubation in accordance to the ISO methods (ISO 6579, 2002).

\section{Water analysis}

The counts for APC and E. coli were carried out using the surface spread technique (on MacConkey Agar [Oxoid, Basingstoke, UK]). For water, APC and E. coli were obtained by pouring $100 \mathrm{ml}$ of the sampled water onto a filter paper (pore size $0.44 \mu \mathrm{m}$ ) to trap as well as isolate bacteria. Following filtration, the filter paper was then placed in a Petri dish, holding the PCA (Oxoid Basingstoke, UK), cooled and incubated at $35^{\circ} \mathrm{C}$ for $48 \mathrm{~h}$. Further isolation of $E$. coli was performed using eosin methylene blue (EMB) agar (Oxoid, Basingstoke, UK). The Petri dishes were incubated for $24 \mathrm{~h}$ at $35^{\circ} \mathrm{C}$. Greenish metallic blue colonies in EMB agar were regarded as presumptive for E. coli. Biochemical tests, for example, indole and catalase tests, were utilized to confirm the $E$. coli isolates. Indole Kovac's reagent was clear and light yellow in color (ISO 4883, 2014; ISO 21528-2, 2004).

\section{Statistical analysis}

Data on microbiological count were first transformed to $\log$ (base 10) prior the analysis using Excel worksheet for easy comparison and were presented as means, standard deviation, and standard errors of the mean. The effects of month, meat type, and season on water microbial count were assessed with the use of the generalized linear model procedures of the statistical analysis system (SAS, 2009). Significant differences among group means were tested with the use of least significant differences, and the statistical significance level was set at $p \leq 0.05$. The results for the microbiological counts were also compared with the National Directorate Veterinary Quarantine and Public Health (VPN15 and 16) standards for meat and water $[13,14]$. 


\section{Results}

\section{Microbial count in RD and PS data sets}

The results from the RD indicate that the APC for beef ranged from 2.51 to $4.32 \mathrm{log} \mathrm{CFU} / \mathrm{cm}^{2}$, and the Enterobacteriaceae count for beef was between 2.58 and $3.91 \log \mathrm{CFU} / \mathrm{cm}^{2}$. The APC for mutton ranged from 2.48 to $4.38 \log \mathrm{CFU} / \mathrm{cm}^{2}$, and the Enterobacteriaceae count for mutton was between 2.48 and $3.45 \log \mathrm{CFU} / \mathrm{cm}^{2}$ (Tables-2 and 3). Water values for APC and Enterobacteriaceae were 1.711.91 and 1.58-1.80 CFU/ml, respectively (Table-4).

In the PS, no significant differences in APC across all meat were noted. Equally, no significant difference $(\mathrm{p}>0.05)$ for Enterobacteriaceae for all meat types was noted. Specifically, the highest APCs for beef, mutton, and water were $3.54 \log \mathrm{CFU} / \mathrm{cm}^{2}$,
$4.14 \log \mathrm{CFU} / \mathrm{cm}^{2}$, and $3.2 \log \mathrm{CFU} / \mathrm{cm}^{2}$, respectively. The highest Enterobacteriaceae counts for beef, mutton, and water were $2.96 \log \mathrm{CFU} / \mathrm{cm}^{2}, 3.9 \mathrm{log} \mathrm{CFU} /$ $\mathrm{cm}^{2}$, and $3.2 \log \mathrm{CFU} / \mathrm{cm}^{2}$, respectively (Table-5). Both Salmonella and E. coli were detected in 50\% of beef. Even though there was no E. coli on mutton, Salmonella was detected in $66.7 \%$ of mutton samples. None of the water samples was positive for Salmonella, but $91.7 \%$ were positive for $E$. coli (Table-6). The mean APCs for beef, mutton, and water were $2.2(\mathrm{SD}: \pm 0.74), 3.0(\mathrm{SD}: \pm 0.49)$, and 1.9 SD: \pm 0.26$)$, respectively (Table-7).

\section{Discussion}

\section{APC and Enterobacteriaceae}

Mishandling of meat has been identified as among the major public health issues. Sanitation and

Table-2: Retrospective microbial count of beef from different abattoirs in the Eastern Cape Province.

\begin{tabular}{|c|c|c|c|c|c|c|}
\hline Date & Location & Abattoir & $\begin{array}{c}\text { Number of } \\
\text { samples }\end{array}$ & $\begin{array}{l}\text { Site } \\
\text { swabbed }\end{array}$ & $\begin{array}{l}\text { APC }(\log \\
\left.\mathrm{CFU} / \mathrm{cm}^{2}\right)\end{array}$ & $\begin{array}{c}\text { Enterobacteriaceae } \\
\left(\log \mathrm{CFU} / \mathrm{cm}^{2}\right)\end{array}$ \\
\hline \multirow[t]{2}{*}{24 May 2017} & Aliwal North & $\mathrm{K}$ & 2 & NA & 4.00 & ND \\
\hline & & & & & 4.28 & ND \\
\hline \multirow{2}{*}{24 May 2017} & Barkely East & $\mathrm{L}$ & 2 & NA & 2.95 & 2.88 \\
\hline & & & & & ND & ND \\
\hline \multirow[t]{4}{*}{12 June 2017} & East London & $\mathrm{H}$ & 4 & Neck & ND & ND \\
\hline & & & & Rump & ND & ND \\
\hline & & & & Flank & ND & ND \\
\hline & & & & Brisket & 4.01 & ND \\
\hline \multirow[t]{4}{*}{03 July 2017} & Adelaide & ] & 4 & Neck & ND & 3.28 \\
\hline & & & & Rump & ND & ND \\
\hline & & & & Flank & 3.71 & ND \\
\hline & & & & Brisket & 3 & 2.90 \\
\hline \multirow[t]{4}{*}{06 August 2017} & Stutterheim & M & 4 & Neck & ND & ND \\
\hline & & & & Brisket & 3.52 & 3.18 \\
\hline & & & & Flank & 2.96 & 2.94 \\
\hline & & & & Rump & ND & ND \\
\hline \multirow[t]{9}{*}{26 September 2017} & Matatiele & G & 9 & Carcass & 2.59 & 2.61 \\
\hline & & & & Carcass & 2.88 & 2.84 \\
\hline & & & & Carcass & 3.06 & 2.83 \\
\hline & & & & Carcass & ND & ND \\
\hline & & & & Carcass & ND & ND \\
\hline & & & & Carcass & 3.00 & 2.95 \\
\hline & & & & Carcass & ND & ND \\
\hline & & & & Carcass & 2.69 & 2.58 \\
\hline & & & & Carcass & ND & ND \\
\hline \multirow[t]{3}{*}{26 September 2017} & East London & $\mathrm{H}$ & 3 & Brisket & ND & ND \\
\hline & & & & Flank & 2.84 & 2.74 \\
\hline & & & & Neck & ND & 3.00 \\
\hline \multirow[t]{2}{*}{10 October 2017} & Elliot & $\mathrm{F}$ & 2 & Rump & 2.58 & 2.69 \\
\hline & & & & Neck & ND & 2.99 \\
\hline \multirow[t]{3}{*}{18 October 2017} & Indwe & $\mathrm{D}$ & 3 & Neck & 2.65 & 2.95 \\
\hline & & & & Flank & 2.83 & 2.81 \\
\hline & & & & Rump & ND & ND \\
\hline \multirow[t]{3}{*}{24 October 2017} & East London & $E$ & 3 & Flank & ND & ND \\
\hline & & & & Rump & ND & ND \\
\hline & & & & Neck & ND & 3.91 \\
\hline \multirow[t]{2}{*}{27 November 2017} & Indwe & $\mathrm{D}$ & 2 & Brisket & 4.32 & ND \\
\hline & & & & Rump & 4.01 & ND \\
\hline \multirow[t]{4}{*}{09 December 2017} & Elliot & $\mathrm{F}$ & 5 & Rump & ND & ND \\
\hline & & & & Brisket & 4.09 & 3.18 \\
\hline & & & & Neck & 2.70 & ND \\
\hline & & & & Flank & 2.51 & ND \\
\hline
\end{tabular}

APC - Aerobic Plate Count. ND - Not Detected. VPN15 standards for meat, Aerobic plate count (3.5 log CFU/cm²- 5.0 $\log$ CFU/ $\mathrm{cm}^{2}$ ), Enterobacteriaceae (1.5 log - $2.5 \mathrm{log}$ CFU/ $\mathrm{cm}^{2}$ ), E. coli (0 log - 1 log CFU/ $\mathrm{cm}^{2}$ ), Salmonella Absent/25 g, $\mathrm{NA}=$ Information missing 
Table-3: Retrospective microbial count of mutton and lamb from different abattoirs in the Eastern Cape Province.

\begin{tabular}{|c|c|c|c|c|c|c|}
\hline Date & Location & Abattoir & $\begin{array}{l}\text { Number of } \\
\text { samples }\end{array}$ & $\begin{array}{l}\text { Site } \\
\text { swabbed }\end{array}$ & $\begin{array}{l}\text { APC }(\log \\
\left.\text { CFU } / \mathrm{cm}^{2}\right)\end{array}$ & $\begin{array}{c}\text { Enterobacteriaceae } \\
\left(\log \mathrm{CFU} / \mathrm{cm}^{2}\right)\end{array}$ \\
\hline \multirow[t]{4}{*}{07 March 2017} & King Williams Town & $\mathrm{C}$ & 4 & Flank & 3.12 & 2.61 \\
\hline & & & & Brisket & ND & ND \\
\hline & & & & Neck & 2.51 & ND \\
\hline & & & & Rump & ND & 2.48 \\
\hline \multirow[t]{4}{*}{29 March 2017} & King Williams Town & $\mathrm{C}$ & 4 & Neck & 4.07 & 2.72 \\
\hline & & & & Brisket & 4.20 & 2.95 \\
\hline & & & & Flank & 4.38 & ND \\
\hline & & & & Rump & 3.40 & 3.17 \\
\hline \multirow[t]{4}{*}{29 March 2017} & East London & $\mathrm{H}$ & 4 & Rump & 3.50 & 2.52 \\
\hline & & & & Neck & 3.88 & 3.28 \\
\hline & & & & Flank & 4.15 & 3.45 \\
\hline & & & & Brisket & 2.77 & 3.06 \\
\hline \multirow[t]{4}{*}{13 June 2017} & East London & $E$ & 4 & Rump & 2.64 & ND \\
\hline & & & & Brisket & 2.61 & 3.03 \\
\hline & & & & Flank & 2.61 & 2.61 \\
\hline & & & & Neck & 4.26 & 3.02 \\
\hline \multirow[t]{4}{*}{10 September 2017} & Komga & $\mathrm{O}$ & 4 & Rump & ND & ND \\
\hline & & & & Neck & 2.69 & ND \\
\hline & & & & Brisket & 3.67 & 3.29 \\
\hline & & & & Flank & 3.33 & 2.84 \\
\hline \multirow[t]{2}{*}{18 September 2017} & Barckely East & $\mathrm{L}$ & 2 & Carcass & 2.52 & 2.68 \\
\hline & & & & & ND & ND \\
\hline \multirow[t]{4}{*}{17 October 2017} & Komga & 0 & 4 & Neck & 3.39 & 2.63 \\
\hline & & & & Rump & ND & ND \\
\hline & & & & Flank & 3.32 & 2.84 \\
\hline & & & & Brisket & 2.89 & 2.62 \\
\hline \multirow[t]{3}{*}{23 October 2017} & Adelaide & J & 6 & Rump & ND & ND \\
\hline & & & & Brisket & 3.30 & 3.18 \\
\hline & & & & Neck & ND & ND \\
\hline \multirow[t]{3}{*}{09 December 2017} & Komga & $\mathrm{O}$ & 4 & Rump & 2.48 & ND \\
\hline & & & & Brisket & ND & ND \\
\hline & & & & Neck & 2.64 & 2.49 \\
\hline
\end{tabular}

APC - Aerobic Plate Count. ND - Not Detected. VPN15 standards for meat, Aerobic plate count $\left(3.5 \mathrm{log}\right.$ CFU/ $\mathrm{cm}^{2}-$ $\left.5.0 \log C F U / \mathrm{cm}^{2}\right)$, Enterobacteriaceae $\left(1.5 \mathrm{log}-2.5 \log \mathrm{CFU} / \mathrm{cm}^{2}\right)$, E. coli $\left(0 \log -1 \mathrm{log} \mathrm{CFU} / \mathrm{cm}^{2}\right)$, Salmonella Absent $/ 25 \mathrm{~g}$

Table-4: Microbial count of tap water used by different abattoirs in the Eastern Cape Province.

\begin{tabular}{|c|c|c|c|c|c|c|}
\hline Date & Location & Abattoir & $\begin{array}{c}\text { No. of } \\
\text { Samples }\end{array}$ & $\begin{array}{l}\text { Sample } \\
\text { type }\end{array}$ & $\begin{array}{l}\text { APC }(\log \\
\text { CFU/ml }\end{array}$ & $\begin{array}{c}\text { Enterobacteriaceae } \\
(\log \mathrm{CFU} / \mathrm{ml})\end{array}$ \\
\hline \multirow[t]{2}{*}{29 July 2017} & Enoch Sontonga & $\mathrm{S}$ & 2 & Tap water & 1.76 & 1.59 \\
\hline & & & & Tap water & 1.71 & ND \\
\hline \multirow[t]{3}{*}{17 October 2017} & Komga & $\mathrm{O}$ & 3 & Tap water & 1.91 & 1.58 \\
\hline & & & & Tap water & ND & ND \\
\hline & & & & Tap water & 1.91 & 1.80 \\
\hline \multirow[t]{2}{*}{27 November 2017} & Indwe & $\mathrm{D}$ & 2 & Tap water & ND & 1.79 \\
\hline & & & & Tap water & ND & ND \\
\hline
\end{tabular}

APC - Aerobic Plate Count, ND - Not Detected

hygiene are essential factors that contribute to meat contamination at the abattoir. Studies have indicated a direct relationship between sanitary conditions at abattoirs and the level of APC and Enterobacteriaceae and $E$. coli counts of raw meat $[15,16]$. However, in the current study, the results for the retrospective and prospective survey demonstrate that all the count for APC and Enterobacteriaceae was within the acceptable limits as stipulated in the South African policy on the microbiological monitoring of meat, process hygiene, and cleaning [13]. The South African policy specifies the acceptable limits for APC as (i) acceptable (3.5 log), (ii) marginal ( $\leq 5.0 \mathrm{log}$ ), and (iii) unacceptable $(>5.0 \mathrm{log})$ and $E$. coli as (i) acceptable (a) if counts are $\leq 1 \mathrm{CFU} / \mathrm{cm}^{2}(0 \log )$; (ii) marginal (m) if counts are $\leq 10 \mathrm{CFU} / \mathrm{cm}^{2}(1 \mathrm{log})$; and (iii) unacceptable (u) if counts are $\left.>10 \mathrm{CFU} / \mathrm{cm}^{2}\right]$ [13].

Similar results were reported in Spain, Switzerland, Korea, New Zealand, and Uganda, where APC and E. coli were reported to be between 2 and $4.5 \log C F U / \mathrm{cm}^{2}$ [1,17-19]. On the contrary, other studies conducted in Ghana and Egypt had higher APC, E. coli, and Enterobacteriaceae counts, ranging from 5.7 to $6 \log \mathrm{CFU} / \mathrm{cm}^{2}$, respectively [20,21]. This result shows that sufficient hygiene measures were in place at the abattoirs involved in this study, which result in the low numbers of bacterial count in meat. Nonetheless, the occurrence of E. coli is 
Table-5: Prospective microbial count Aerobic plate count and Enterobacteriaceae on beef, mutton and water.

\begin{tabular}{|c|c|c|c|}
\hline Date & Meat & APC $\left(\log C F U / \mathrm{cm}^{2}\right)$ & Enterobacteriaceae $\left(\log \mathrm{CFU} / \mathrm{cm}^{2}\right)$ \\
\hline \multirow{3}{*}{18 February 2018} & Mutton & 0 & 0 \\
\hline & Mutton & 3.98 & 0 \\
\hline & Mutton & 2.52 & 2.96 \\
\hline \multirow[t]{3}{*}{20 February 2018} & Mutton & 2.71 & 2.56 \\
\hline & Mutton & 4.3 & 0 \\
\hline & Mutton & 2.51 & 0 \\
\hline \multirow[t]{4}{*}{05 February 2018} & Mutton & 0 & 0 \\
\hline & Mutton & 4.14 & 0 \\
\hline & Mutton & 3.48 & 0 \\
\hline & Mutton & 3.54 & 0 \\
\hline \multirow[t]{2}{*}{27 February 2018} & Water & 1.87 & 0 \\
\hline & Water & 0 & 3.2 \\
\hline 19 February 2018 & Water & 2.09 & 1.76 \\
\hline \multirow[t]{2}{*}{18 February 2018} & Water & 2.08 & 1.83 \\
\hline & Water & 2.08 & 1.9 \\
\hline \multirow[t]{2}{*}{02 June 2018} & Water & 2.05 & 1.54 \\
\hline & Water & 1.69 & 0 \\
\hline \multirow[t]{2}{*}{31 January 2018} & Water & 1.97 & 0 \\
\hline & Water & 2.93 & 0 \\
\hline \multirow[t]{2}{*}{13 March 2018} & Water & 1.95 & 1.86 \\
\hline & Water & 2 & 2 \\
\hline \multirow[t]{3}{*}{04 November 2018} & Water & 1.51 & 0 \\
\hline & Water & 2.36 & 0 \\
\hline & Water & 3.2 & 0 \\
\hline 19 February 2018 & Water & 0 & 1.76 \\
\hline \multirow[t]{2}{*}{18 February 2018} & Water & 2.08 & 1.83 \\
\hline & Water & 2.08 & 1.9 \\
\hline \multirow[t]{2}{*}{02 June 2018} & Water & 2.05 & 1.54 \\
\hline & Water & 1.69 & 0 \\
\hline \multirow[t]{2}{*}{31 January 2018} & Water & 1.97 & 0 \\
\hline & Water & 2.93 & 0 \\
\hline \multirow[t]{2}{*}{13 January 2018} & Water & 1.95 & 1.86 \\
\hline & Water & 2 & 2 \\
\hline \multirow[t]{2}{*}{04 November 2018} & Water & 1.51 & 0 \\
\hline & Water & 2.36 & 0 \\
\hline \multirow[t]{4}{*}{18 February 2018} & Beef & 3.54 & 2.5 \\
\hline & Beef & 3.98 & 3.9 \\
\hline & Beef & 2.52 & 2.96 \\
\hline & Beef & 2.3 & 0 \\
\hline
\end{tabular}

VPN15 standards for meat, Aerobic plate count (3.5 log CFU $/ \mathrm{cm}^{2}-5.0 \mathrm{log} \mathrm{CFU} / \mathrm{cm}^{2}$ ), Enterobacteriaceae $\left(1.5 \mathrm{log}-2.5 \mathrm{log} C F U / \mathrm{cm}^{2}\right)$, E. coli $\left(0 \mathrm{log}-1 \mathrm{log} C F U / \mathrm{cm}^{2}\right)$, Salmonella Absent $/ 25 \mathrm{~g}$

Table-6: Salmonella and Escherichia coli detection in beef, mutton and water.

\begin{tabular}{lccccccc}
\hline Species & \multicolumn{3}{c}{ Salmonella } & & \multicolumn{3}{c}{ Enterobacteriaceae } \\
\cline { 2 - 4 } \cline { 2 - 4 } & $\mathbf{+ ( \% )}$ & $\mathbf{- ( \% )}$ & 土SD & & $\mathbf{+ ( \% )}$ & $\mathbf{- ( \% )}$ & 土SD \\
\hline Beef & 50 & 50 & 0.58 & & 50 & 50 & 0.58 \\
Mutton & 33.3 & 66.7 & 0.49 & & ND & 100 & 0.00 \\
Water & ND & 100 & 0.00 & & 8.3 & 91.7 & 0.28
\end{tabular}

+ Positive - Negative, SD-Standard deviation, ND-Not detected

Table-7: Aerobic plate count and Enterobacteriaceae count in beef mutton and water.

\begin{tabular}{lccccc}
\hline Species & \multicolumn{2}{c}{ APC } & & \multicolumn{2}{c}{ Enterobacteriaceae } \\
\cline { 2 - 3 } \cline { 5 - 6 } & $\boldsymbol{\mu} \pm$ SE & $\#$ & & $\boldsymbol{\mu} \pm$ SE & $\#$ \\
\hline Beef & $2.2 \pm 0.74$ & Ns & & $1.0 \pm 0.74$ & Ns \\
Mutton & $3.0 \pm 0.49$ & Ns & & $0.4 \pm 0.49$ & Ns \\
Water & $1.9 \pm 0.26$ & Ns & & $1.0 \pm 0.26$ & Ns \\
\hline
\end{tabular}

$\mu$-Mean, SE-Standard error, APC-Aerobic plate count.

\# significance, Ns-Not significant, ** significant at $\mathrm{P} \leq 0.05$ of concern as some strains like E. coli O:157: H7 associated with the production of Shiga toxins have been reported to be the cause of foodborne illness in humans [22-24].

Other pathogroups, including enterotoxigenic $E$. coli and enteroaggregative $E$. coli, diffusely adherent $E$. coli, and enterohemorrhagic $E$. coli, are regularly transmitted to humans through the consumption of contaminated water and meat [25-27]. In the present study, no significant difference $(\mathrm{p}>0.05)$ was noted for Enterobacteriaceae in both beef and mutton. The result of APC is similar to that of Enterobacteriaceae for all types of meat. Hence, we suspect that the minimal contamination took place during animal slaughter. Studies conducted in the USA and Latvia also reported no significant difference $(\mathrm{p}>0.05)$ in Enterobacteriaceae and APC beef, minced meat, breaded pork, smoked meat products, chop, different types of sausages, aspic, and liver pate [28-30]. 


\section{Salmonella}

This study found Salmonella in 50\% of beef and mutton. In studies conducted in South Africa, Turkey, Denmark, and Egypt, the prevalence of Salmonella was found to be $3 \%, 5 \%, 10 \%$, and $33 \%$, respectively [31-33]. However, there was no Salmonella detected in another South African study [34]. Salmonella is still among the top five foodborne pathogenic bacteria causing remarkable health problems to consumers. In low- and middle-income countries, the lack of an epidemiological surveillance system makes it hard to assess the incidence of salmonellosis in both human and animals [33]. Hence, the recovery of Salmonella from meat is a public health hazard, with extreme consequences for children, older adults, people with HIV/AIDS, and pregnant people [35]. The rate of Salmonella found in this study proposes that meat acquired from the sampling area pose a public health hazard to consumers and hence compromises the quality of meat [13], thus highlighting the need for abattoirs to review their hygiene systems with the objective of identifying risk factors for Salmonella cross-contamination.

\section{Water}

E. coli and other coliform bacteria are ideal indicators of water quality [36]. The South African government standards on water stipulate zero $(0 \mathrm{log}$ $\mathrm{CFU} / 100 \mathrm{ml}$ ) for $E$. coli or coliforms and $100 \mathrm{CFU} / \mathrm{ml}$ in water for total plate counts [14]. However, 91.7\% of water samples in the current study tested positive for E. coli, Enterobacteriaceae, and APC ranged from 1.0 to $3.20 \log \mathrm{CFU} / \mathrm{ml}$. Enterobacteriaceae consists of a group of Gram-negative bacteria known to cause infections such as urinary tract infections, meningitis, cystitis, pneumonia, wound sepsis, and bacteremia [37]. Hence, the presence of Enterobacteriaceae poses remarkable public health risk if found in food and water. Such risk could further be worsened if the bacteria already have antimicrobial resistance, such as multidrug resistance. Water in prior studies had been linked to increase in bacterial count and could contribute to further spread of contamination of carcasses $[10,38]$. The result of bacterial counts in meat in the current study closely mirrors those of water; hence, we hypothesize that the water used for carcass washing could be responsible for carcass contamination.

\section{Conclusion}

This study found that even though the beef and mutton from the abattoir were of good, acceptable microbial quality, the presence of E. coli in water compromised the quality of meat generated in such abattoirs. The observed levels of E. coli have the potential to predispose the meat to contamination with pathogenic E. coli. Because the biochemical composition of meat makes it ideal for the rapid proliferation of bacteria once contaminated, it is important that the sources of water used in abattoir be continuously investigated to eliminate or reduce the risk of contamination of meat processed in the abattoirs. Meat hygiene must also be maintained throughout the value chain for meat and meat products to protect the consumer's health. Therefore, regular microbial testing during singeing, blasting and chilling of meat as part of monitoring the product while in production, in line with the principles of HACCP, should be implemented. Moreover, training of abattoir workers is needed to enhance hygienic skills as well as improve microbial meat quality. Remedial actions aimed at preventing the transmission of Salmonella either from the environment or through fecal contamination should be implemented.

\section{Authors' Contributions}

PN carried out the research and wrote the manuscript. IFJ designed the study, supervised the research, and edited the manuscript. JWO edited the manuscript and made a useful contribution to the study design. All authors read and approved the final manuscript.

\section{Acknowledgments}

We are grateful to the Department of Rural Development and Agrarian Reform (DrDAR), and Queenstown Veterinary Clinic for providing the data. We are also thankful to the Govan Mbeki Research and Development Center (GMRDC), University of Fort Hare, South Africa, and National Research Fund (NRF), South Africa, for financial support (Animal product safety- project grant No. 140702).

\section{Competing Interests}

The authors declare that they have no competing interests.

\section{Publisher's Note}

Veterinary World remains neutral with regard to jurisdictional claims in published institutional affiliation.

\section{References}

1. Ibrahim, M., Amin, A., Saleh, A. and Shafay, E. (2013) Quality of beef and edible offal at abattoir level. Benha Vet. Med. J., 25(2): 254-263.

2. Huang, R., Dawson, C.O. and Hussain, M.A. (2014) Microbiological quality of selected meat products from the Canterbury Region of New Zealand. Food Saf., 16(1): 12-16.

3. Tanih, N.F., Sekwadi, E., Ndip, R.N. and Bessong, P.O. (2015) Detection of pathogenic Escherichia coli and Staphylococcus aureus from cattle and pigs slaughtered in abattoirs in Vhembe District, South Africa. Sci. World J., 2015(1): 195972.

4. Ateba, C.N. and Mbewe, M. (2011) Detection of Escherichia coli $\mathrm{O} 157: \mathrm{H} 7$ virulence genes in isolates from beef, pork, water, human and animal species in the Northwest Province, South Africa: Public health implications. Res. Microbiol., 162(3): 240-248.

5. Mendes Guerra, M.M., deAlmeida,A.M. and Willingham,A.L. (2016) An overview of food safety and bacterial foodborne zoonoses in food production animals in the Caribbean region. Trop. Anim. Health Prod., 48(6): 1095-1108.

6. Shonhiwa, A.M., Ntshoe, G., Essel, V., Thomas, J. and Mccarthy, K. (2017) A Review of Foodborne Disease 
Outbreaks Reported to the Outbreak Response Unit, National Institute for Communicable Diseases, South Africa, 2013-2017, Int. J. Inf. Dis., 79(1): 1-150.

7. Mazizi, B.E. and Muchenje, V. (2017) Assessment of aerobic plate counts, Staphylococcus aureus, Escherichia coli and Salmonella in meat sold by street vendors in the Eastern Cape Province, South Africa. J. Food Nutr. Res., 5(6): 436-442.

8. Havelaar, A.H., Kirk, M.D., Torgerson, P.R., Gibb, H.J., Hald, T., Lake, R.J., Praet, N., Bellinger, D.C., Silva, N.R., de Gargouri, N., Speybroeck, N., Cawthorne, A., Mathers, C., Stein, C., Angulo, F.J., Devleesschauwer, B. and World Health Organization Foodborne Disease Burden Epidemiology Reference Group. (2015) World Health Organization global estimates and regional comparisons of the burden of foodborne disease in 2010. PLoS Med., 12(12): e1001923.

9. Majowicz, S.E., Scallan, E., Jones-Bitton, A., Sargeant, J.M., Stapleton, J., Angulo, F.J., Yeung, D.H. and Kirk, M.D. (2014) Global incidence of human shiga toxin-producing Escherichia coli infections and deaths: A systematic review and knowledge synthesis. Foodborne Pathog. Dis., 11(6): 447-455.

10. Jaja, I., Green, E. and Muchenje, V. (2018) Aerobic mesophilic, coliform, Escherichia coli, and Staphylococcus aureus counts of raw meat from the formal and informal meat sectors in South Africa. Int. J. Environ. Res. Public Health, 15(4): 819.

11. Statistics South Africa. (2018) Statistics South Africa: Midyear Population Estimates, Pretoria, South Africa. Available from: http://www.statssa.gov.za/?s=mid-year+population+estimates\&sitem=publication. Retrieved on $24-10-2018$.

12. Soji, Z., Chikwanda, D., Chikwanda, A.T., Jaja, I.F., Mushonga, B. and Muchenje, V. (2015) Relevance of the formal red meat classification system to the South African informal livestock sector. S. Afr. J. Anim. Sci., 45(3): 263-277.

13. NDVQPH. (2010) Standard for the Microbiological Monitoring of Meat, Process Hygiene and Cleaning, Pretoria, South Africa. Available from: http://www.nda. agric.za/vetweb/VPN\&SOP/VPN15-standardformicrobi ologicalmonitoringofmeat 15-03-2010.pdf. Retrieved on 28-12-2018.

14. VPN16. (2000) Standard for the microbiological monitoring of water. In: Self-Compacting Concrete. p1-7. Available from: https://www.daff.gov.za/daffweb3/branches/agricultural-production-health-food-safety/veterinary-public-health/veterinary-public-health/vpn-sop. Retrieved on 28-12-2017.

15. Salmela, S.P., Fredriksson-Ahomaa, M., Hatakka, M. and Nevas, M. (2013) Microbiological contamination of sheep carcasses in Finland by excision and swabbing sampling. Food Control, 31(2): 372-378.

16. Katsande, T.C. and Govender, R. (2014) A microbiological survey of fresh meat processed at abattoirs in Gauteng, South Africa. J. New Gener. Sci., 12(2): 29-42. Available from: https://www.journals.co.za/docserver/fulltext/newgen $/ 12 / 2 /$ newgen_v12_n2_a3.pdf?expires $=1566243780$ \&id $=\mathrm{id} \&$ accname $=$ guest $\&$ checksum $=5$ D 5632E2232A3B12455456536001AD4A. Retrieved on 19-08-2019.

17. Zweifel, C. and Stephan, R. (2003) Microbiological monitoring of sheep carcass contamination in three swiss abattoirs. J. Food Prot., 66(6): 946-952.

18. Rivas, T., Pala, P. and Sevilla, A. (2004) Microbial contamination of carcasses, meat, and equipment from an Iberian pork cutting plant. J. Food Prot., 67(8): 1624-1629.

19. Zweifel, C., Capek, M. and Stephan, R. (2014) Microbiological contamination of cattle carcasses at different stages of slaughter in two abattoirs. Meat Sci., 98(2): 198-202.

20. Ayum, G. and Gifty, A. (2010) Microbial quality of chevon and mutton sold in Tamale Metropolis of Northern Ghana. J. Appl. Sci. Environ. Manag., 14(4): 53-55.

21. Khalafalla, F.A., Fatma, Ali, H.M., Hassan, A.R.H. and El-Feky, K.A. (2016) Monitoring the bacterial contamination during different stages of beef carcass preparation at Beni-Suef abattoir, Egypt. Benha. Vet. Med. J., 30(1): 51-58.

22. Kawano, K., Okada, M., Haga, T., Maeda, K. and Goto, Y. (2008) Relationship between pathogenicity for humans and stx genotype in Shiga toxin-producing Escherichia coli serotype O157. Eur. J. Clin. Microbiol. Infect. Dis., 27(3): 227-232.

23. Gyles, C.L. (2007) Shiga toxin-producing Escherichia coli: An overview. J. Anim. Sci., 85(13): 45-62.

24. Pennington, H. (2010) Escherichia coli O157. Lancet, 376(9750): 1428-1435.

25. Iweriebor, B.C., Iwu, C.J., Obi, L.C., Nwodo, U.U. and Okoh, A.I. (2015) Multiple antibiotic resistances among Shiga toxin-producing Escherichia coli $\mathrm{O} 157$ in feces of dairy cattle farms in Eastern Cape of South Africa. BMC Microbiol., 15(1): 213.

26. Caine, L.A., Nwodo, U.U., Okoh, A.I., Ndip, R.N. and Green, E. (2014) Occurrence of virulence genes associated with diarrheagenic Escherichia coli isolated from raw cow's milk from two commercial dairy farms in the Eastern Cape Province, South Africa. Int. J. Environ. Res. Public Health, 11(11): 11950-11963.

27. Kabiru, L.M., Bello, M., Kabir, J., Grande, L. and Morabito, S. (2015) Detection of pathogenic Escherichia coli in samples collected at an abattoir in Zaria, Nigeria and at different points in the surrounding environment. Int. $J$. Environ. Res. Public Health, 12(1): 679-691.

28. Nou, X., Rivera-Betancourt, M., Bosilevac, J.M., Wheeler, T., Lford, S.D., Gwartney, B.L., Reagan, J.O. and Koohmaraie, M. (2003) Effect of chemical dehairing on the prevalence of Escherichia coli $\mathrm{O} 157: \mathrm{H} 7$ and the levels of aerobic bacteria and Enterobacteriaceae on carcasses in a commercial beef processing plant. J. Food Prot., 66(11): 2005-2009.

29. Arthur, T.M., Bosilevac, J.M., Nou, X., Shackelford, S.D., Wheeler, T.L., Kent, M.P., Jaroni, D., Pauling, B., Allen, D.M. and Koohmaraie, M. (2004) Escherichia coli O157 prevalence and enumeration of aerobic bacteria, Enterobacteriaceae, and Escherichia coli $\mathrm{O} 157$ at various steps in commercial beef processing plants. J. Food Prot., 67(4): 658-665.

30. Melngaile, A., Ciekure, E. and Valcina, O. (2014) Microbiological quality of meat preparations and meat products. Foodbalt, 2(1): 61-65.

31. Fachmann, M.S.R., Löfström, C., Hoorfar, J., Hansen, F., Christensen, J., Mansdal, S. and Josefsen, M.H. (2017) Detection of Salmonella enterica in meat in less than 5 hours by a low-cost and noncomplex sample preparation method. Appl. Environ. Microbiol., 83(5): 1-10.

32. Eyigor, A., Temelli, S. and Carli, K.T. (2012) Salmonella detection in poultry meat and meat products by the Vitek immunodiagnostic assay system easy Salmonella method, a light cycler polymerase chain reaction system, and the international organization for standardization method 6579. Poult. Sci., 91(3): 724-731.

33. Jaja, I.F., Bhembe, N.L., Green, E., Oguttu, J. and Muchenje, V. (2019) Molecular characterisation of antibiotic-resistant Salmonella enterica isolates recovered from meat in South Africa. Acta Trop., 190(1): 129-136. Available from: https://www.linkinghub.elsevier.com/retrieve/pii/ S0001706X18311562. Retrieved on 26-11-2018.

34. Nyamakwere, F., Muchenje, V., Mushonga, B., Makepe, M. and Mutero, G. (2016) Assessment of Salmonella, Escherichia coli, Enterobacteriaceae and aerobic colony counts contamination levels during the beef slaughter. $J$. Food Saf., 36(4): 548-556.

35. Mhone, T.A., Matope, G. and Saidi, P.T. (2011) Aerobic 
bacterial, coliform, Escherichia coli and Staphylococcus aureus counts of raw and processed milk from selected smallholder dairy farms of Zimbabwe. Int. J. Food Microbiol., 151(2): 223-228.

36. Abera, B., Bezabih, B. and Hailu, D. (2017) Microbial quality of community drinking water supplies: A ten year (2004-2014) analyses in West Amhara, Ethiopia. Sustain. Water Qual. Ecol., 9-10(1): 22-26. Available from: https://www.sciencedirect.com/science/article/pii/
S221261391630037X. Retrieved on 05-02-2019.

37. AlTamimi, M., AlSalamah, A., AlKhulaifi, M. and AlAjlan, H. (2017) Comparison of phenotypic and PCR methods for detection of carbapenemases production by Enterobacteriaceae. Saudi J. Biol. Sci., 24(1): 155-161.

38. Bello, M., Lawan, M.K., Kwaga, J.K.P. and Raji, M.A. (2011) Assessment of carcass contamination with E. coli O157 before and after washing with water at abattoirs in Nigeria. Int. J. Food Microbiol., 150(2-3): 184-186.

$* * * * * * * *$ 